Research paper

\title{
Identifying a reliable target fraction for radiocarbon dating sedimentary records from lakes
}

\author{
Jamie D. Howarth ${ }^{\mathrm{a}, *}$, Sean J. Fitzsimons ${ }^{\mathrm{a}}$, Geraldine E. Jacobsen ${ }^{\mathrm{b}}$, Marcus J. Vandergoes ${ }^{\mathrm{c}}$, \\ Richard J. Norris ${ }^{\mathrm{d}}$ \\ a Department of Geography, University of Otago, PO Box 56, Dunedin, Otago 9056, New Zealand \\ ${ }^{\mathrm{b}}$ Institute for Environmental Research, Australian Nuclear Science and Technology, Organization, Locked Bag 2001, Kirrawee DC, NSW 2232, Australia \\ ${ }^{c}$ GNS Science, PO Box 30-368, Lower Hutt, New Zealand \\ ${ }^{\mathrm{d}}$ Department of Geology, University of Otago, PO Box 56, Dunedin, New Zealand
}

\section{A R T I C L E I N F O}

\section{Article history:}

Received 13 December 2012

Received in revised form

12 February 2013

Accepted 14 February 2013

Available online 26 February 2013

\section{Keywords:}

Lake sediment

Radiocarbon

Pollen

Macrofossils

Old carbon

\begin{abstract}
A B S T R A C T
Lake basins that experience rapid rates of deposition act as high-resolution environmental archives because they produce sedimentary records that have centennial or even decadal resolution. However, identifying target fractions for radiocarbon dating of lake sediments remains problematic because reworked organic material from fluvial catchments can produce anomalously old radiocarbon ages. This study determines the extent to which reworked material from catchment soils impacts radiocarbon dates on pollen and other organic concentrates by comparing radiocarbon dates produced by these techniques against a chronostratigraphic marker in cores from Lake Mapourika, New Zealand. Pollen preferentially preserved and reworked from catchment soils was identified using soil palynology. A technique was then developed to remove reworked pollen types from pollen concentrates extracted from lake sediment. Identification and removal of reworked pollen from pollen concentrates produced ages that were consistently closer to the age of the chronostratigraphic horizon than other organic concentrates. However, these dates were still between 736 and 366 calendar years older than expected. The only organic fractions that reliably reproduced the age of the chronostratigraphic horizon were terrestrial leaf macrofossils, although terrestrial leaf macrofossils isolated from megaturbidite deposits, which are formed by high-energy depositional events, also provided anomalously old ages. The results indicate that leaf material extracted from hemipelagite, which accumulates gradually, is likely to be the only organic fraction to produce reliable chronology in lakes where a component of sedimentation is driven by the fluvial system. The results also demonstrate the importance of conducting a detailed investigation of physical sedimentology before selecting material for radiocarbon dating lake sediments.
\end{abstract}

Crown Copyright @ 2013 Published by Elsevier B.V. All rights reserved.

\section{Introduction}

Lake sediments are excellent proxy records that provide continuous and high-resolution archives of environmental change (Last and Smol, 2001). The need for high-resolution paleoclimate and paleoseismic records (e.g. Moy et al., 2011; Waldmann et al., 2011) has resulted in increasing use of lake basins that have high sedimentation rates driven in part by the fluvial system (e.g. Moy et al., 2011, 2008; Schnellmann et al., 2002). High sedimentation lake basins offer a distinct advantage over smaller, closed, lake basins because the high sedimentation rate produces records that

\footnotetext{
* Corresponding author. University of Otago, PO Box 56, Dunedin, 9050, New Zealand. Tel.: +64 34703566 .

E-mail address: jdh@geography.otago.ac.nz (J.D. Howarth).
}

have centennial or even decadal resolution. Establishing precise chronology is an essential component of any reconstruction using such sediments because the chronology must have a comparable resolution to the events being reconstructed. Radiocarbon $\left({ }^{14} \mathrm{C}\right)$ dating of organic material within lake sediments remains the most widely used technique for establishing chronology, and the development of Bayesian statistical approaches to analysing ${ }^{14} \mathrm{C}$ datasets can produce chronologies that have near decadal precision (Blockley et al., 2007; Bronk Ramsey, 2008). Despite the development of age modelling techniques the accuracy of ${ }^{14} \mathrm{C}$ chronologies remains reliant on the ${ }^{14} \mathrm{C}$ dates providing an accurate age for sediment deposition.

The relationship between a ${ }^{14} \mathrm{C}$ date and the depositional age of sediment is particularly important for lakes where sedimentation is driven by the fluvial system. In such settings, storage, episodic 
fluvial re-working and deposition of organic material from catchment soils ("old" carbon) can dilute the ${ }^{14} \mathrm{C}$ content of the organic material with respect to the atmosphere at the time of deposition, causing ages to be older than the depositional event within which the carbon is embedded (Bertrand et al., 2012; Colman et al., 2004; Edwards and Whittington, 2001; McGlone and Wilmshurst, 1999). The problems associated with "old" carbon in lake sediments have driven research into identifying and excluding organic fractions containing old carbon from ${ }^{14} \mathrm{C}$ dating targets (e.g. Brown et al., 1989; Turney et al., 2000). Such research has demonstrated that leaf material from terrestrial plants is the most reliable fraction for dating lake sediments. Their terrestrial origin means that leaves have ${ }^{14} \mathrm{C}$ concentrations in equilibrium with the atmosphere and their delicate structure precludes long residence times in lake catchments before deposition in lake basins (Oldfield et al., 1997; Turney et al., 2000). Although terrestrial macrofossils are reliable targets, in many depositional settings they are rare and may not occur in sufficient abundance to allow high-precision chronology to be established.

An alternative organic fraction that has been widely used in situations where terrestrial macrofossils are scarce is pollen isolated from lake sediments (Brown et al., 1989; Chester and Prior, 2004; Long et al., 1992; Newnham et al., 2007; Moy et al., 2011; Vandergoes and Prior, 2003). Pollen is predominantly of terrestrial origin and is generally thought to be incorporated into sediment through continuous pollen rain from the atmosphere, making it relatively abundant (Brown et al., 1989; Vandergoes and Prior, 2003). A growing number of studies have argued that ${ }^{14} \mathrm{C}$ dates derived from pollen concentrates provide ages contemporaneous with sediment deposition (Brown et al., 1989; Chester and Prior, 2004; Vandergoes and Prior, 2003). However, some studies that have tested the accuracy of pollen concentrate ages against independent chronological markers have concluded that pollen concentrates may yield ages that are consistently older than the depositional age of the sediment (Kilian et al., 2002; Mensing and Southon, 1999). Fluvial reworking of pollen from catchment soils has been proposed as the most likely cause of anomalous ${ }^{14} \mathrm{C}$ ages produced from pollen concentrates (Mensing and Southon, 1999).

Reworked pollen from catchment soils has considerable implications for studies using pollen concentrates to establish highprecision chronology in lakes where fluvial sedimentation is a significant component of deposition. Despite this, there has not been a systematic analysis of the impact of reworked pollen and other organic material on ${ }^{14} \mathrm{C}$ ages from lake sediments. In this paper we determine whether reworked material from soils make ${ }^{14} \mathrm{C}$ dates on pollen and other organic concentrates substantially older than expected. The study focuses on Lake Mapourika, New Zealand (Fig. 1). Lake Mapourika is located adjacent to the Alpine Fault and its catchment drains the range front topography of the Southern Alps. The sedimentary record from the lake contains deposits formed by large earthquakes on the Alpine Fault, which have been precisely dated using terrestrial leaf macrofossil datasets from multiple lakes (Howarth et al., 2012; Howarth, 2012). The coseismic deposits provide chronostratigraphic horizons in both basins of the lake, which provide an independent test for the accuracy of the pollen and organic concentrate dates. We use the results of the test to develop a dating strategy for lakes where fluvial sediment flux dominates deposition.

\section{Study setting}

Lake Mapourika is situated $3.5 \mathrm{~km}$ from the surface trace of the Alpine Fault where it strikes along the base of the range front of the Southern Alps (Fig. 1). The lake is $8.3 \mathrm{~km}^{2}$ and is composed of two basins separated by a $5 \mathrm{~m}$ high sill. The southern basin has a maximum depth of $\sim 75 \mathrm{~m}$, while the northern basin has a maximum depth of $\sim 77.8 \mathrm{~m}$ (Irwin, 1979). Both basins are characterised by relatively flat basin floors and steep sides that are continuous with the subaerial slopes of a latero-terminal moraine complex bounding the lake. The $66.3 \mathrm{~km}^{2}$ fluvial catchment of the lake drains predominantly into the southern basin and has $1820 \mathrm{~m}$ of relief between the highest peaks and lake level. There are also a number of subsidiary streams that drain into Lake Mapourika's northern basin from the low relief moraine complex west of the Alpine Fault. The catchment is covered with native podocarp/ hardwood temperate rainforest below the treeline at $1000 \mathrm{~m}$ a.s.l (Wardle, 1991).

The sediments of Lake Mapourika are characterised by a repeating sequence of three deposits (Howarth, 2012). The depositional sequence starts with megaturbidite deposits characterised by a normally graded, sandy silt base, overlain by relatively thick, homogeneous, very fine sandy silt that is capped with a thin layer of medium silt (Fig. 2 A). Megaturbidites are the thickest deposits in the centre of both lake basins, they can be traced across the lake
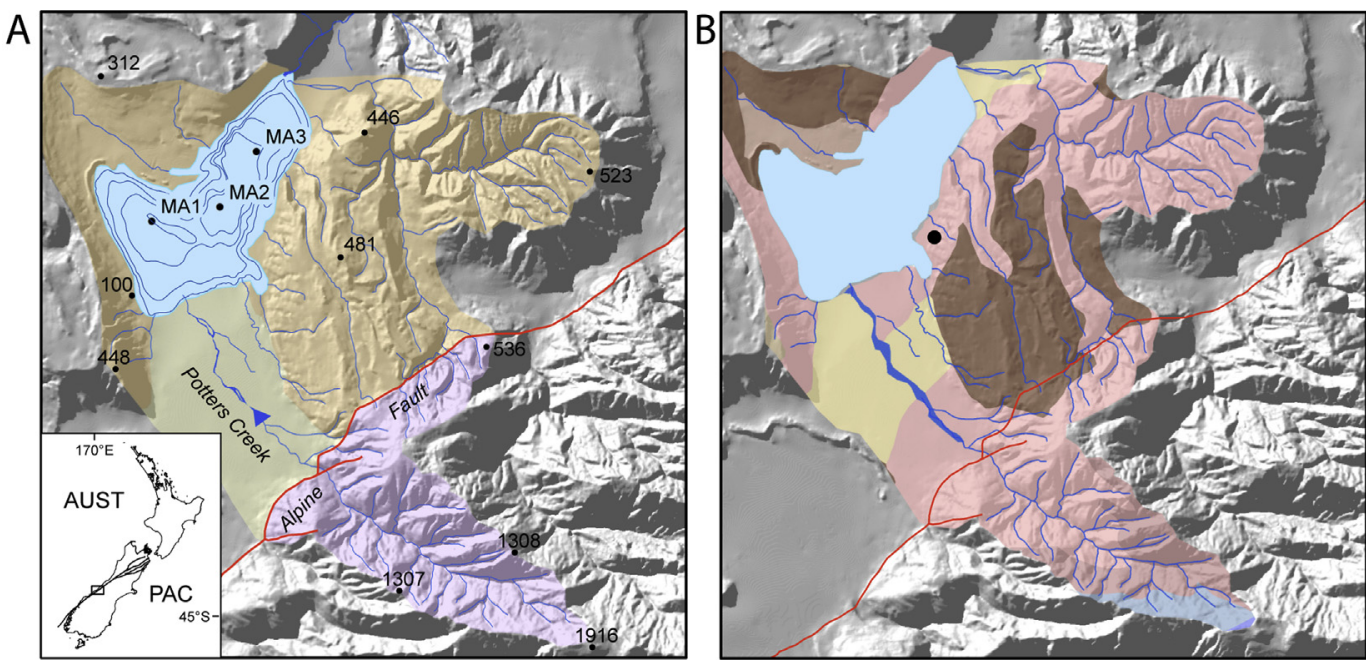

Soil Class

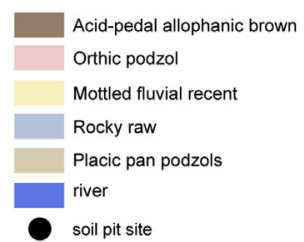

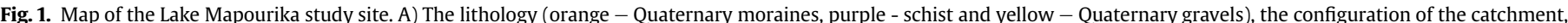

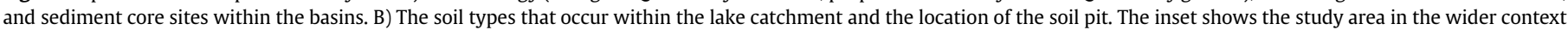
of New Zealand. Pac. - Pacific plate, Aust. - Australian plate and red line - Alpine Fault. 


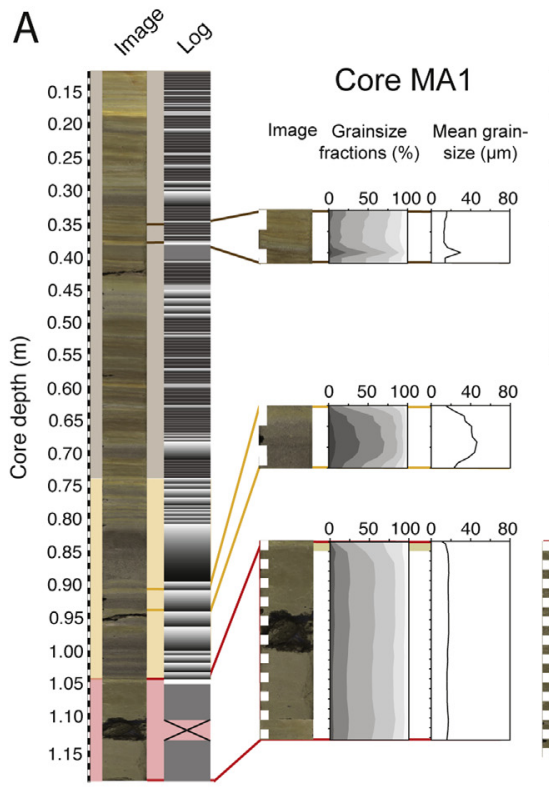

B

B

Core MA1 Core MA2 Core MA3

Key for Log $\begin{array}{ll}\square \text { Megaturbidite } & \text { Megaturbidite correlation } \\ \square_{\text {turbidite }}^{\text {Hyperpycnal }} & \text { Chronostratigraphic } \\ \text { horizon }\end{array}$

国 Hemipelagite

Mass-flow

Terrestrial macrofossil

Core MA2

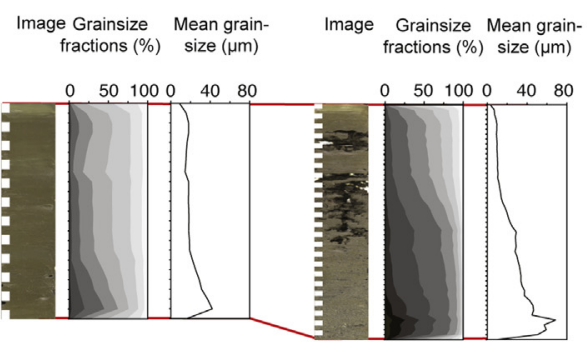

Key for grainsize fractons

$\begin{array}{ll}\square \text { Very coarse sand } & \square \text { Fine sand } \\ \text { Coarse sand } & \square \text { Cory fine sand } \\ \text { Medium sand } & \square \text { Medium silt } \quad \square \text { Clay } \\ \text { Very coarse silt } & \square \text { Fine silt }\end{array}$

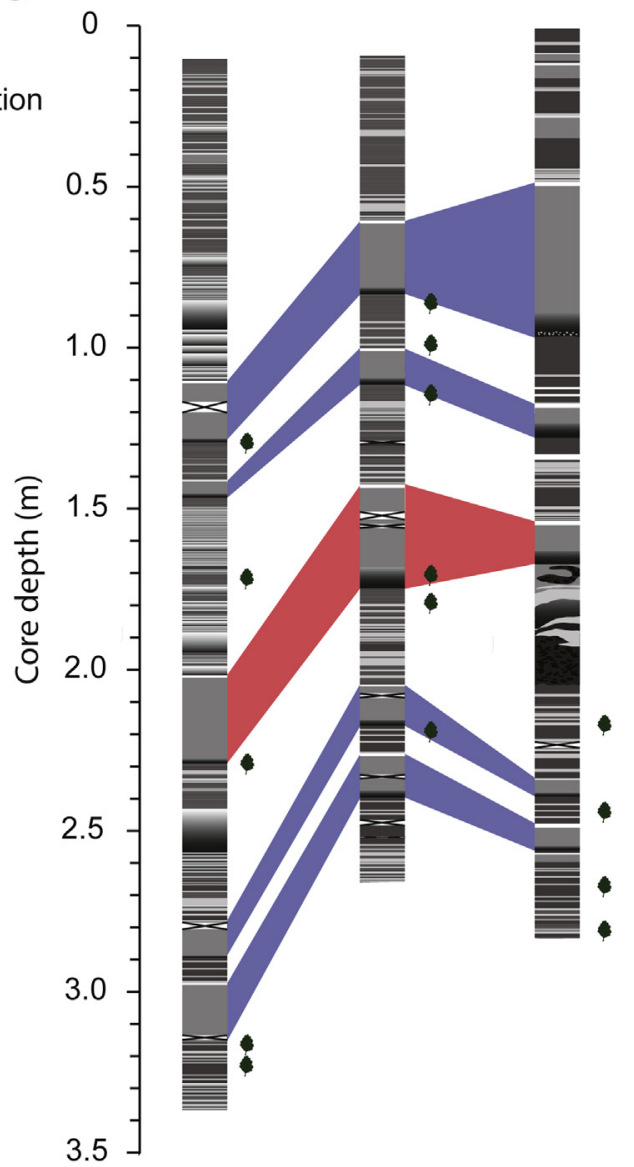

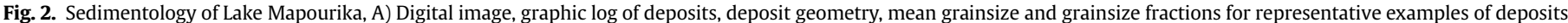

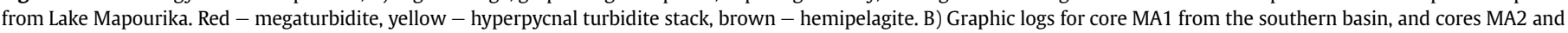
MA3 from the northern basin of Lake Mapourika. The chronostratigraphic horizon is shown in red.

basins, and they are thickest in the deepest part of the lake. The sedimentology and geometry of megaturbidites is indicative of formation by coseismically triggered subaqueous massmovements (Beck, 2009; Howarth et al., 2012; Schnellmann et al., 2002). Megaturbidites are generally overlain by a stack of turbidites characterised by inversely graded fine sandy silt that transition into normally graded medium silt, both of which have high $\mathrm{C} / \mathrm{N}$ ratios, indicative of terrestrial sourced carbon. The turbidite stacks are interpreted as the product of fluvial hyperpycnal flows, which record elevated postseismic sediment flux caused by earthquake-induced landsliding (Howarth, 2012; Howarth et al., 2012). Stacks of hyperpycnal turbidites transition into fine, sandy to medium silts that are deposited during periods of relatively low sediment flux between Alpine Fault earthquakes and are termed hemipelagite. An exception to the sequence described above is the absence of hyperpycnite stacks in cores from the northern basin due to the absence of direct fluvial inflow from large streams (Fig. 2B).

\section{Methods}

Pollen from catchment soils was identified and ${ }^{14} \mathrm{C}$ dated to determine the pollen types that were preferentially preserved in soils, and to assess the extent to which reworking could bias ages derived from pollen concentrates. Comparisons were then made between ${ }^{14} \mathrm{C}$ dates derived from pollen concentrates, bulk sediment humin, bulk sediment humic compounds, macro organic detritus, organic detritus and macrofossils from above, within and below the third megaturbidite (MT3) in core MA2, which represents a chronostratigraphic marker horizon (Fig. 2). Pollen fractions were also extracted from above and below the same megaturbidite in core MA1 to confirm the results (Fig. 2).

\subsection{Soil palynology}

The composition of pollen from catchment soils was assessed using pollen from soil samples retrieved from a $1 \mathrm{~m} \times 1 \mathrm{~m} \times 0.5 \mathrm{~m}$ soil pit excavated in an orthic podzol, which is the dominant soil type in the Lake Mapourika catchment (Rijkse and Hewitt, 1995, Fig. 1). Soil samples were recovered from the leaf litter horizon, organic horizon (O), topsoil horizon (A), eluviated horizon (E) and subsoil-regolith horizon (BC).

Soil samples were dried at $35^{\circ} \mathrm{C}$ and homogenised. Pollen was extracted from $1 \mathrm{~g}$ sub-samples from each soil horizon using standard extraction procedures to remove carbonates, non-pollen organic material and silicates (Faegri and Iversen, 1989; Vandergoes and Fitzsimons, 2003). The pollen concentrates were mounted on slides and 300 grains counted and identified using microscopy. Pollen types were identified with reference to Moar (1993), Large and Braggins (1991) and Pocknall (1981a,b), and classified according to the nomenclature of Moar et al. (2011). Percentage pollen data was calculated from the raw pollen counts using the programme Tilia (Grimms, 1991) and plotted graphically using TGView (Grimms, 1995). 
3.2. Bulk sediment humin, humic acid and macrofossil pre-treatment for ${ }^{14} \mathrm{C}$ dating

Macrofossil material was extracted from sediment and physically cleaned by washing in deionised water (DIW) and scraping with a scalpel to remove any sediment attached to the surface. Cleaned macrofossils and $3 \mathrm{~g}$ samples of bulk sediment were subjected to a standard A-A-A (acid-alkali-acid) pre-treatment procedure to remove carbonates, fulvic compounds and humic compounds following the methods of Hua et al. (2001).

The humic acid fraction was extracted from bulk sediment samples by isolating the humics extracted during the alkali treatments of the bulk sediment samples. The humic compounds were then precipitated by acidifying with $2 \mathrm{M} \mathrm{HCl}$. The precipitated humic compounds were centrifuged at $3500 \mathrm{rpm}$ for $20 \mathrm{~min}$ to separate them from the supernatant. The humic compounds were rinsed in DIW and then purified by re-dissolving them in $0.5 \mathrm{M}$ $\mathrm{NaOH}$ and re-precipitating them with $\mathrm{HCl}$. After the purification all sample fractions were dried at $65{ }^{\circ} \mathrm{C}$ for $24 \mathrm{~h}$ before being loaded into combustion tubes for conversion to $\mathrm{CO}_{2}$.

\subsection{Pollen concentration and pre-treatment for ${ }^{14} \mathrm{C}$ dating}

Pollen was concentrated for ${ }^{14} \mathrm{C}$ dating from $50 \mathrm{~g}$ samples of dry lake sediment using a procedure modified from Newnham et al. (2007) that combines isolation of pollen by sieving and heavy liquid separations using lithium heteropolytungstate (LST), and chemical pre-treatment to remove contaminants (Fig. 3). Sieving steps at $37 \mu \mathrm{m}$ and $25 \mu \mathrm{m}$ were added to the procedure to remove pollen types that were identified, using the soil palynology and dating, as preferentially preserved in the catchment soils (see Section 4.1). Suitable mesh diameters for this step were determined by measuring the shortest axis of two pollen types: 1) Dacrydium cupressinum, which is not preferentially preserved in catchment soils and is the target fraction for dating; and 2) Cyathea smithii, which is preferentially preserved in catchment soils and needed to be excluded from the target fraction.

To assess the success of the pollen concentration procedure the relative proportions of $D$. cupressinum, Podocarp, $C$. smithii, other pollen and organic detritus were determined by counting 250 particles from each of the following fractions: $1.3>x>1.1 \mathrm{s.g}$. $90>x>37 \mu \mathrm{m}, 1.3>x>1.1$ s.g. $37>x>25 \mu \mathrm{m}$, and $1.3>x>1.1$ s.g. $25>x>10 \mu \mathrm{m}$. The pollen concentration procedure used to isolate $C$. smithii spores produced relatively pure pollen concentrates that contained between $80 \%$ and $90 \%$ pollen (Fig. 4 ; Table 1 ). The sieving step at $25 \mu \mathrm{m}$ effectively excluded $C$. smithii spores, reducing the abundance of these spores in the target fraction ( $37>x>25 \mu \mathrm{m}$ and $1.3>x>1.1 \mathrm{~s} \mathrm{~g}$ ) to less than 5\% (Fig. 4; Table 1). Sieving at $37 \mu \mathrm{m}$ or $43 \mu \mathrm{m}$ was also effective at removing organic detritus. Following pre-treatment the pollen concentrate fractions were freeze-dried and loaded into combustion tubes for conversion to $\mathrm{CO}_{2}$.

To test whether the pollen concentration procedure introduced significant amounts of contamination in the form of modern carbon a blank sample was processed using the same method, and dated. The blank samples were polleniferous sediment from Pukaki Maar

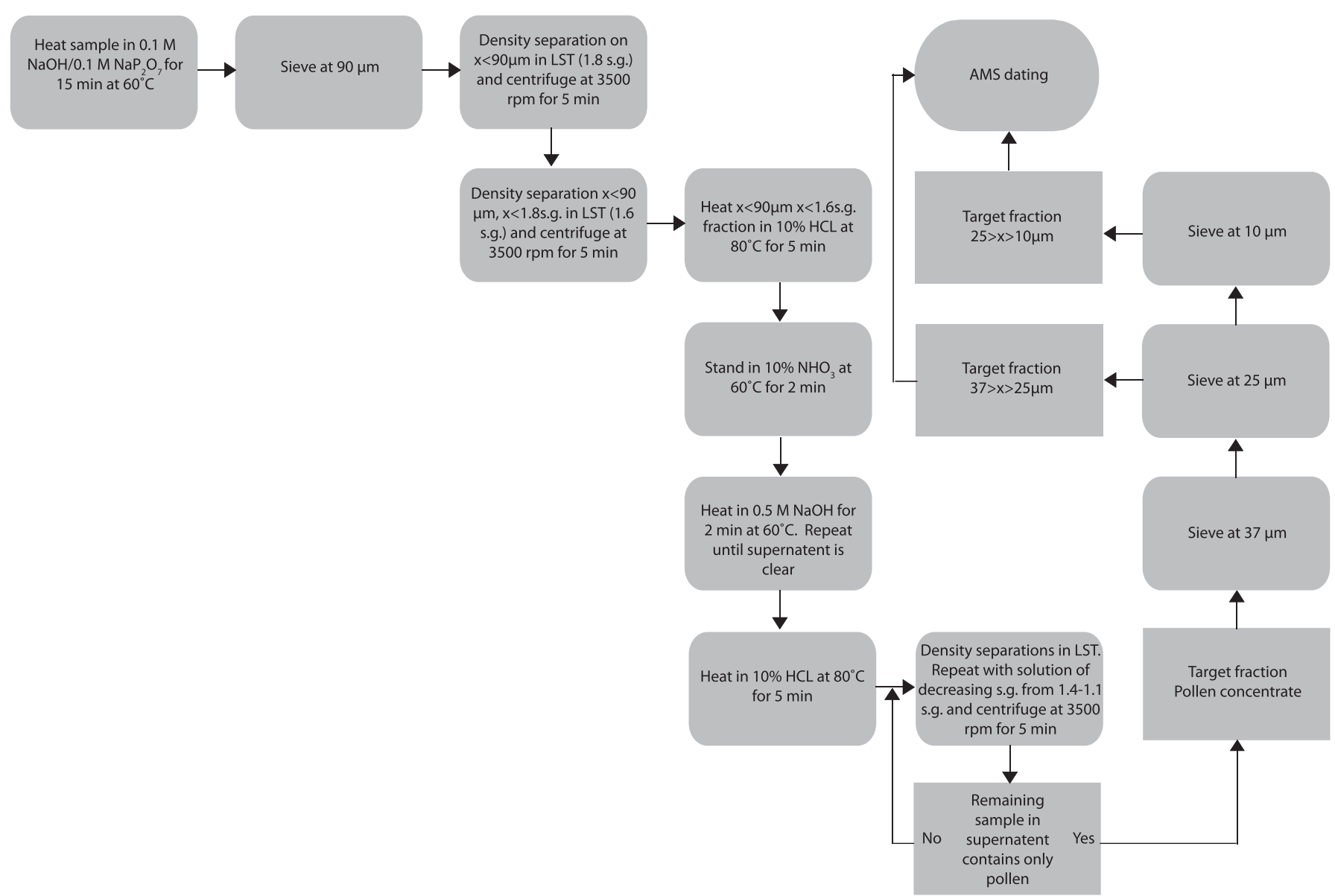

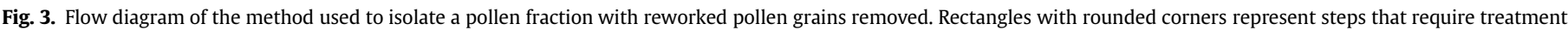
of the samples; rectangles with sharp corners represent steps that require an assessment of the target fraction; and ovals are the method outputs. 

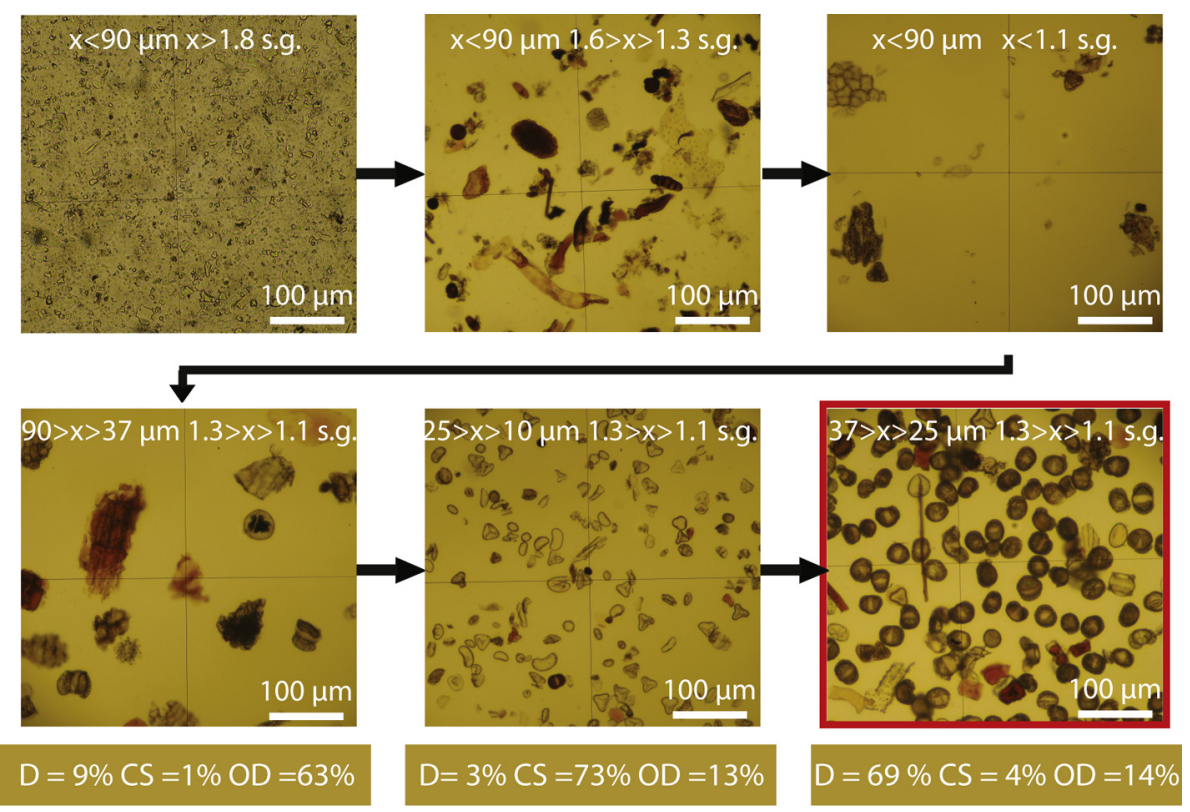

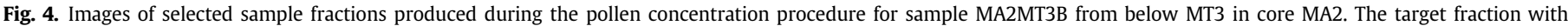

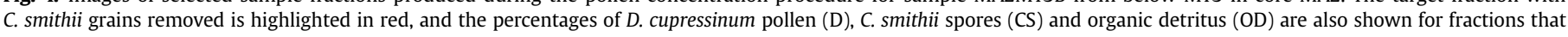
contain pollen. (For interpretation of the references to colour in this figure legend, the reader is referred to the web version of this article.)

Lake, Auckland, New Zealand and were extracted from $72 \mathrm{~m}$ subbottom depth with an estimated age of 90,000 yr BP, which is well beyond the $\geq 55,000{ }^{14} \mathrm{C}$ yr BP background of ${ }^{14} \mathrm{C}$ dating (Hua et al., 2001). ${ }^{14} \mathrm{C}$ ages for the blank samples provided ages very close to background suggesting that the pollen concentration procedure does not introduce significant amounts of modern carbon contamination (Table 2).

\section{4. $\mathrm{CO}_{2}$ extraction and graphisation}

The pre-treated ${ }^{14} \mathrm{C}$ targets from pollen, organic concentrate, macrofossil and bulk sediment fractions were converted to $\mathrm{CO}_{2}$ using the sealed-tube method of Hua et al. (2001) at the Australian Nuclear Science and Technology Organization (ANSTO). $\mathrm{CO}_{2}$ was converted to graphite by reduction using excess hydrogen in the presence of an iron catalyst at $600 \mathrm{C}$ for $12 \mathrm{~h}$. Once completed, the graphite and iron mixture was pressed into aluminium cathodes for ${ }^{14} \mathrm{C}$ measurement by Accelerator Mass Spectrometry (AMS) at ANSTO following methods outlined in Fink et al. (2004). All ${ }^{14} \mathrm{C}$ measurements were normalised against the NIST standard of oxalic acid I (HOxI). Sub-samples of the graphite were analysed for $\delta{ }^{13} \mathrm{C}$ using a continuous flow isotope ratio mass spectrometer (EA-IRMS), and the raw ${ }^{14} \mathrm{C}$ results corrected for isotopic fractionation using measured $\delta{ }^{13} \mathrm{C}$. The ${ }^{14} \mathrm{C}$ results were reported as percent Modern Carbon (pMC), as described in Stuiver and Polach (1977).

\subsection{Developing an age model for the Lake Mapourika sedimentary record}

Chronology for the Lake Mapourika sedimentary record was established using $20{ }^{14} \mathrm{C}$ dates on terrestrial leaf macrofossils isolated from hemipelagite deposits. The radiocarbon dates were combined with core depth information and the SHCal 04 calibration curve using the P_sequence depositional model in OxCal 4.1 (Bronk Ramsey, 2008; Howarth, 2012; McCormac et al., 2004). The P_sequence model was run with the constant " $k$ " set to 3 , a value that has been empirically derived for similar lake settings in Westland (Howarth, 2012). Stratigraphic information was derived from core depth records that were normalised to remove depth associated with rapidly deposited layers (RDL), such as megaturbidites and hyperpycnites, that had thicknesses greater than $5 \mathrm{~mm}$. These deposits were removed because they do not represent the significant passage of time as they were deposited in days to weeks whereas the maximum resolution of the radiocarbon chronology is

Table 1

Composition of the pollen and organic detritus fractions isolated using the pollen concentration procedure.

\begin{tabular}{|c|c|c|c|c|c|c|c|}
\hline Sample & Fraction & Pollen (\%) & D. cupressinum (\%) & Podocarp (\%) & C. smithii (\%) & Other (\%) & $\begin{array}{l}\text { Organic } \\
\text { detritus (\%) }\end{array}$ \\
\hline MA2MT3T & $90>x>43 \mu \mathrm{m} 1.3>x>1.1 \mathrm{s.g}$. & 24 & 2 & 15 & 3 & 5 & 76 \\
\hline MA2MT3T & $43>x>25 \mu \mathrm{m} 1.3>x>1.1 \mathrm{s.g}$. & 69 & 42 & 14 & 4 & 10 & 31 \\
\hline MA2MT3T & $25>x>10 \mu \mathrm{m} 1.3>x>1.1$ s.g. & 80 & 1 & 0 & 73 & 6 & 20 \\
\hline MA2MT3 & $90>x>31 \mu \mathrm{m} 1.3>x>1.1 \mathrm{s.g}$. & 52 & 20 & 21 & 5 & 5 & 48 \\
\hline MA2MT3 & $25>x>10 \mu \mathrm{m} 1.3>x>1.1 \mathrm{s.g}$. & 80 & 14 & 1 & 64 & 12 & 8 \\
\hline МА2МТ3В & $90>x>37 \mu \mathrm{m} 1.3>x>1.1$ s.g. & 37 & 9 & 22 & 1 & 6 & 63 \\
\hline МА2МТ3В & $37>x>25 \mu \mathrm{m} 1.3>x>1.1 \mathrm{s.g}$. & 86 & 69 & 9 & 4 & 5 & 14 \\
\hline MA2MT3B & $25>x>10 \mu \mathrm{m} 1.3>x>1.1 \mathrm{s.g}$. & 87 & 3 & 1 & 73 & 11 & 13 \\
\hline MA1MT3T & $43>x>25 \mu \mathrm{m} 1.3>x>1.1$ s.g. & 55 & 28 & 13 & 2 & 13 & 45 \\
\hline MA1MT3T & $25>x>10 \mu \mathrm{m} 1.3>x>1.1 \mathrm{s.g}$ & 72 & 3 & 1 & 48 & 21 & 28 \\
\hline MA1MT3B & $90>x>37 \mu \mathrm{m} 1.3>x>1.1 \mathrm{s.g}$. & 39 & 7 & 21 & 1 & 10 & 61 \\
\hline MA1MT3B & $37>x>25 \mu \mathrm{m} 1.3>x>1.1$ s.g. & 87 & 68 & 10 & 5 & 5 & 13 \\
\hline MA1MT3B & $25>x>10 \mu \mathrm{m} 1.3>x>1.1 \mathrm{s.g}$. & 89 & 3 & 1 & 72 & 14 & 11 \\
\hline
\end{tabular}


Table 2

Conventional ${ }^{14} \mathrm{C}$ ages of pollen blank samples from Pukaki Maar Lake.

\begin{tabular}{|c|c|c|c|c|c|}
\hline Sample & Fraction & Fraction content & ${ }^{14} \mathrm{C}$ age (yr BP) & $\delta{ }^{13} \mathrm{C}(\%)$ & Lab code \\
\hline Puk Blank & $37>x>25 \mu \mathrm{m} 1.3>x>1.1$ s.g. & Podocarp pollen & $50,400 \pm 1500$ & $-28.3 \pm 0.1$ & OZN013 \\
\hline Puk Blank & $25>x>10 \mu \mathrm{m} 1.3>x>1.1 \mathrm{s.g}$. & C. smithii spores & $55,100 \pm 1900$ & $-30.2 \pm 01$ & OZN014 \\
\hline
\end{tabular}

years. Model boundaries constrain the age model to the upper and lower ${ }^{14} \mathrm{C}$ dates for the record and internal boundaries were added at $1.04 \mathrm{~m}$ and $1.34 \mathrm{~m}$ on the RDL normalised depth scale to partition two different sedimentary regimes (c.f. Bronk Ramsey, 2008). The change in sedimentary regime was driven by drainage capture of Potters Creek, the major inflow into Lake Mapourika, resulting in a relatively quiescent depositional regime between the boundaries (Howarth, 2012). The age model produced by the above procedure was used to derive the timing of megaturbidite deposition using the date () function (Bronk Ramsey, 2010). The age of the third megaturbidite (MT3) in the sequence was then used as a chronostratigraphic marker to assess the accuracy of ages produced from organic concentrates (details outlined in Section 4.2).

\subsection{Comparison with the age of the chronostratigraphic horizon}

Individual conventional ${ }^{14} \mathrm{C}$ ages from the organic fractions dated were calibrated to produce probability density functions (PDFs) of calendar age estimates using the programme OxCal 4.1 (Bronk Ramsey, 2010) and the Southern Hemisphere calibration curve SHCal 04 (McCormac et al., 2004). Dates older than 10,000 yr BP were calibrated using the INTCal 09 curve (Reimer et al., 2009). Comparisons were made between the calendar ages of organic fractions, including bulk humin, bulk humic acid, macro organic detritus ( $x>90 \mu \mathrm{m}, x<1.8$ s.g.), organic detritus ( $90>x>43 \mu \mathrm{m}$, $1.3>x>1.1$ s.g.), pollen concentrates enriched in $D$. cupressinum pollen, and pollen concentrates enriched in C. smithii spores, with the known age of MT3 using the difference function in OxCal 4.1, which returns the PDF for the difference between the dates (Bronk Ramsey, 2010). All ages are reported as the 95\% highest probability density function (HPDF) calendar age ranges.

\section{Results}

\subsection{Soil stratigraphy, palynology and ${ }^{14} \mathrm{C}$ ages}

The soil profile was characterised by five well-developed soil horizons overlying a fractured schist regolith (Fig. 5). The upper $5 \mathrm{~cm}$ of the soil profile consisted of poorly decomposed leaf litter underlain by a $10 \mathrm{~cm} \mathrm{O}$ horizon characterised by dark brown to black silty loam. The $\mathrm{O}$ horizon was underlain by a $17 \mathrm{~cm}$ A horizon of red brown sandy silt loam that was underlain by a $7 \mathrm{~cm}$ E horizon of grey silty loam. A cemented iron pan separated the $\mathrm{E}$ horizon from a $16 \mathrm{~cm} \mathrm{BC}$ horizon of red brown stony silt loam.

The pollen assemblage of the leaf litter horizon was dominated by $D$. cupressinum, which reached its highest abundance in the soil profile representing $30 \%$ of the total pollen sum (Fig. 5). Other important pollen types in the leaf litter included C. smithii at $17 \%$, Dicksonia squarrosa at $13 \%$, Grislinea spp. at $6 \%$ and Weinmannia racemosa at $6 \%$ of the total pollen sum. The abundance of D. cupressinum decreased to $25 \%$ in the $O$ horizon, while C. smithii increased to $30 \%$. D. squarrosa and Grislinea spp. also decreased in abundance to 5\%, while Aristolia spp. and Ascarina lucida increased to $5 \%$. The other pollen types were all below $5 \%$. The A horizon was dominated by C. smithii, which reached an abundance of $45 \%$ of the total pollen sum. D. cupressinum decreased to $20 \%$ of the total pollen sum and $A$. lucida. was the only other pollen type exceeding $5 \%$. D. cupressinum decreased abruptly to $10 \%$ in the E horizon concomitant with an increase in the abundance of $C$. smithii, which exceeded $50 \%$ of the total pollen sum in this zone. The BC horizon had a similar pollen assemblage to the E horizon, differing in a slight increase in the abundance of $C$. smithii. Down profile shifts in abundance are dominated by a dramatic decrease in $D$. cupressinum concomitant with an increase in C. smithii spores.

Radiocarbon dating of bulk soil humin and pollen concentrates, enriched in $C$. smithii spores $(1.3>x>1.1 \mathrm{s.g} .25>x>10 \mu \mathrm{m})$ and podocarp pollen $(1.3>x>1.1 \mathrm{s.g} .50>x>25 \mu \mathrm{m})$, provided a range of ages for the BC horizon of the soil profile (Table 3 ). The bulk soil humin yielded a calendar age ranging from 6919 to 7255 cal BP. Pollen concentrates exhibited significantly younger ages than the bulk soil humin fraction. The pollen fraction enriched in C. smithii spores produced a calendar age that ranged from 4420 to $4802 \mathrm{cal}$ $\mathrm{BP}$. The pollen concentrate enriched in podocarp pollen provided an even younger calendar age (3471-3695 cal BP). Combined, the ${ }^{14} \mathrm{C}$ ages and soil pollen stratigraphy provide some insight into the potential for fluvial reworking of soil organic material into lake sediments, which is outlined below.

The presence of pollen in catchment soils confirms that soil eroded during landsliding and eventually transported to lake basins will contain pollen that may have been stored on catchment slopes for up to several thousands of years. Inclusion of this pollen in concentrates for ${ }^{14} \mathrm{C}$ dating would bias ${ }^{14} \mathrm{C}$ ages. Consequently, removing reworked pollen types should improve the accuracy of dates derived using this technique but requires reworked grains to be identified.

The trends in abundance of the dominant pollen types down the soil profile provide some insight into the types of pollen that are preferentially preserved in catchment soils and likely to be reworked to the lake basin. The most striking feature of the soil pollen composition is the anti-phase relationship between the abundance of $D$. cupressinum pollen and $C$. smithii spores down the soil profile. There are two plausible explanations for this trend. It may represent the relative abundance of these taxa through the time period of soil development and accumulation. For example, the change in dominance may reflect the role of these species in the succession of forest communities in the study area, which is characterised by a shift from tree ferns, such as $C$. smithii, in early successional communities to $D$. cupressinum as forests reach maturity (Wardle, 1980). Alternatively, the anti-phase relationship in the abundance of $D$. cupressinum and $C$. smithii may represent preferential preservation of decay-resistant pollen and spores.

The latter interpretation is supported by the ${ }^{14} \mathrm{C}$ ages on organic concentrates extracted from the soil. The 2000 calendar year difference in ages for the soil humin and the pollen concentrates (Table 3 ) suggest that the pollen is significantly younger than the soil-forming material. We interpret this difference in age to reflect decomposition of pollen in the soil over time, an interpretation supported by the poor preservation of pollen grains from the BC soil horizon. If pollen has been decaying in-situ then more resistant pollen types should provide older ages than less resistant pollen types. C. smithii has a high sporopollenin content in the spore exine making it highly resistant to decay and increasing its propensity for preservation in soils (Wilmshurst et al., 1999; Wilmshurst and McGlone, 2005). The soil pollen concentrate enriched in C. smithii spores provided an age approximately 1000 calendar years older than the concentrate enriched in podocarp pollen, confirming that 


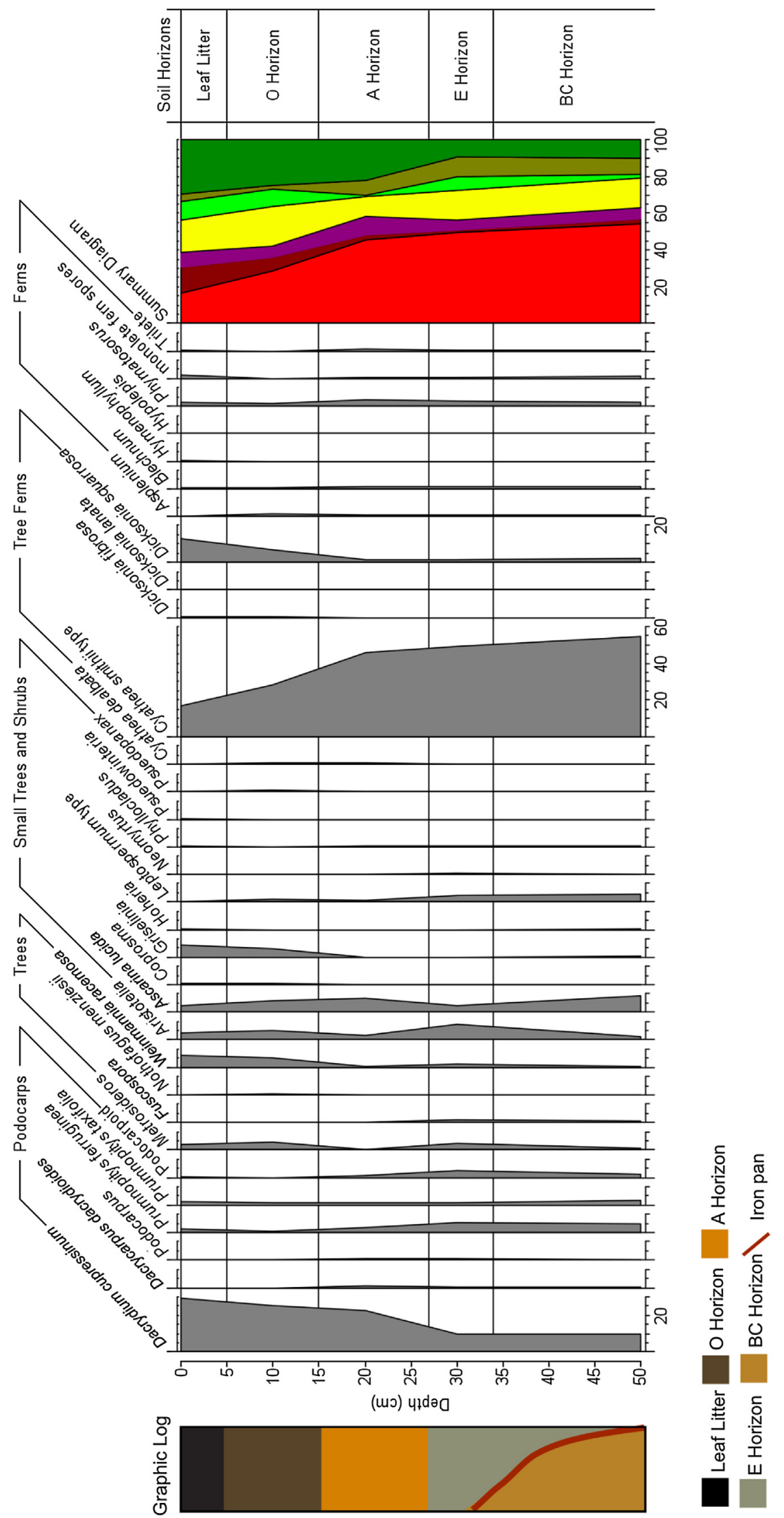

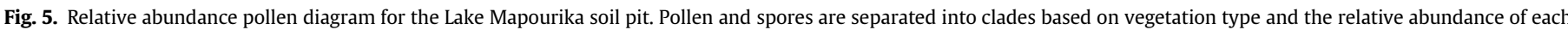

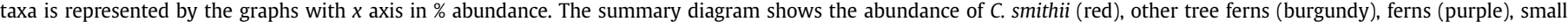

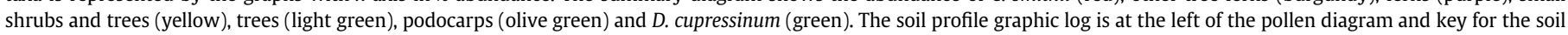
horizons below. 
Table 3

Conventional ${ }^{14} \mathrm{C}$ ages and 95\% highest probability density function (HPDF) calendar age ranges for the organic fractions dated from the lake Mapourika soil pit.

\begin{tabular}{|c|c|c|c|c|c|c|}
\hline Sample & Fraction & Fraction content & ${ }^{14} \mathrm{C}$ age (yr BP) & $\delta{ }^{13} \mathrm{C}(\%)$ & Lab code & $\begin{array}{l}95 \% \text { HPDF calendar } \\
\text { age range (cal BP) }\end{array}$ \\
\hline MSOIL & Bulk humin & Humin & $6240 \pm 60$ & $-21.3 \pm 0.1$ & OZL521 & $6919-7255$ \\
\hline MSOIL & $50>x>\times 25 \mu \mathrm{m} 1.3>x>1.1 \mathrm{s.g}$. & Podocarp pollen & $3410 \pm 40$ & $-26.5 \pm 0.1$ & OZN028 & $3471-3695$ \\
\hline MSOIL & $25>x>10 \mu \mathrm{m} 1.3>x>1.1$ s.g. & C. smithii spores & $4105 \pm 40$ & $-27.8 \pm 0.1$ & OZN029 & $4420-4802$ \\
\hline
\end{tabular}

C. smithii spores are preferentially preserved in catchment soils and are therefore more likely to be reworked into the lake deposits. Consequently, inclusion of $C$. smithii spores in pollen concentrates from lake sediments will bias ${ }^{14} \mathrm{C}$ dates. In order to examine this possibility we removed these spores from pollen concentrates and compared ${ }^{14} \mathrm{C}$ dates from the material with the known age of MT3, which represents a chronostratigraphic horizon.

\subsection{Chronostratigraphic marker horizon}

The age model developed using Bayesian modelling of ${ }^{14} \mathrm{C}$ ages on terrestrial leaf macrofossils isolated from hemipelagite provided a high agreement index of $88.2 \%$, which is well above the $60 \%$ threshold, confirming that the resultant age model exhibits a good fit to the ${ }^{14} \mathrm{C}$ ages (Fig. 6; Bronk Ramsey, 2008). The chronology provides tight constraint ( \pm 15 years) on the timing of megaturbidite deposition, and an age of 543-574 cal BP for the third megaturbidite in the sequence.

The megaturbidites provide chronostratigraphic marker horizons because they are formed by subaqueous slope failures during Alpine Fault earthquakes (Howarth et al., 2012), the impacts of which are regional in extent (Sutherland et al., 2007; Wells et al., 1999). Such deposits can be correlated between multiple lakes along the Alpine Fault, including Lake Mapourika (Howarth, 2012) and their ages are consistent with earthquake ages derived from independent dendrochronology (Howarth et al., 2012; Wells et al., 1999). Consequently, we use MT3 from Lake Mapourika as a chronostratigraphic horizon for comparison with the organic fractions dated in this study.

\subsection{Comparison between organic concentrate ages and the chronostratigraphic horizon}

The bulk sediment humin fraction from the sample of hemipelagite sediment directly overlying MT3 in core MA2 provided a calendar age between 24,371-25,175 cal BP, which is two orders of magnitude older than the depositional age of 543-574 cal BP for the megaturbidite (Fig. $7 \mathrm{~A}$ ). The other organic concentrates isolated from the same sediment provided ages that ranged between 689 and 1510 cal BP, which are also older than the megaturbidite. The difference to the megaturbidite age ranged from 358 to 144 calendar years for humic compounds to 961-748 calendar years for the pollen concentrate dominated by the $C$. smithii spores (Fig. 7A; Table 4). The calendar age PDF for the $C$. smithii-dominated pollen concentrate was significantly older than the other organic fractions and 551-227 calendar years older than the D. cupressinum pollen concentrate.

The bulk sediment humin derived from megaturbidite sediments produced a calendar age ranging from 5746-5935 cal BP, which is the closest of the bulk sediment humin calendar ages to the depositional age of the chronostratigraphic horizon but remains an order of magnitude too old (Fig. 7B). Leaf macrofossils isolated from the megaturbidite sediment yielded a range of calendar ages that were generally older than megaturbidite deposition. The difference between macrofossil calendar ages and the chronostratigraphic horizon ranged from coeval with deposition to
1047-775 calendar years too old (Fig. 7B). The other organic concentrates isolated from megaturbidite sediment also provided ages that were older than the deposition of the chronostratigraphic horizon. The difference between their PDFs and the age of the chronostratigraphic horizon ranged from 593 to 382 calendar years for the pollen concentrate composed predominantly of D. cupressinum to $1475-1177$ calendar years for the fraction composed of bulk sediment humic compounds. The pollen concentrate dominated by $C$. smithii spores provided a calendar age PDF that was between 421 and 171 calendar years older than the concentrate dominated by $D$. cupressinum pollen.

The bulk sediment humin date from the sample of hemipelagite sediment below MT3 provided an age of 10,552-11,090 cal BP,

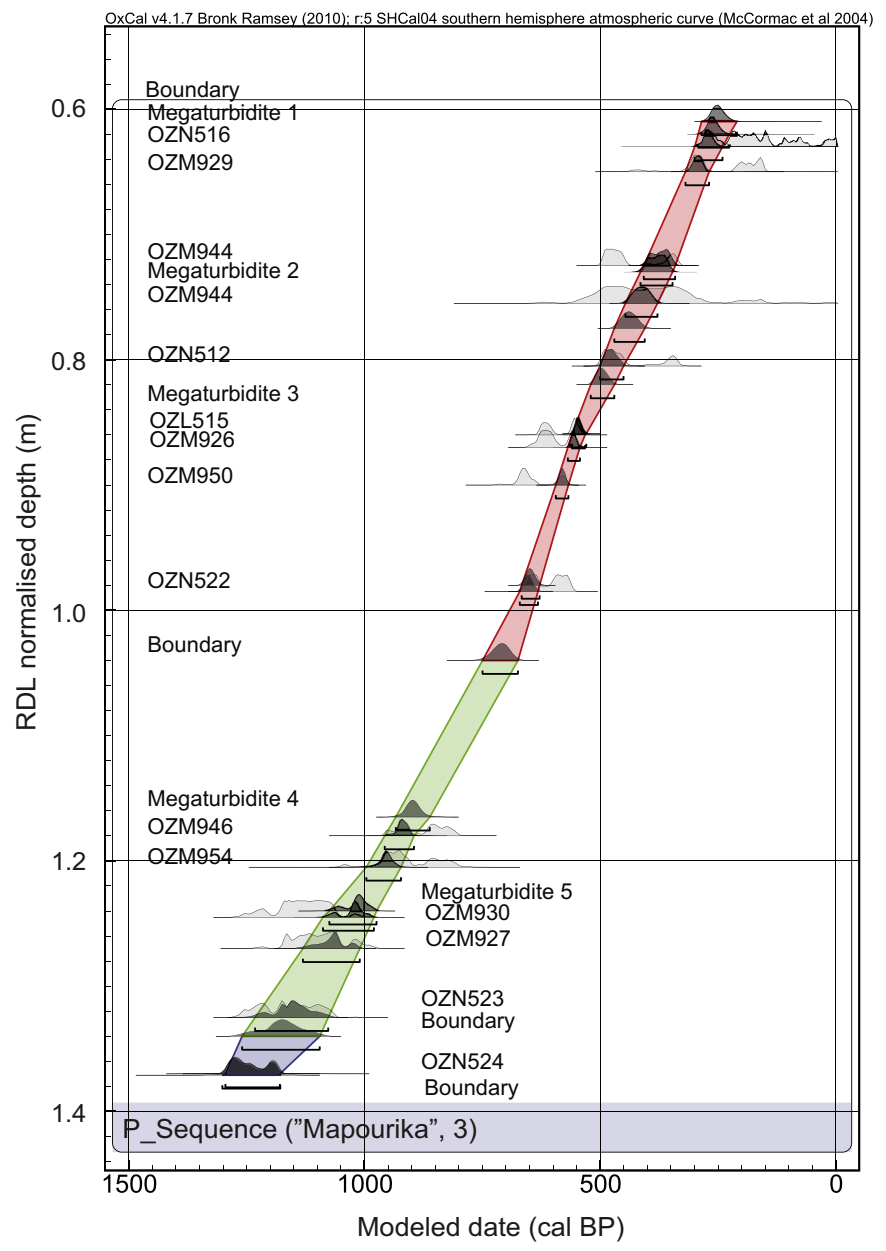

Fig. 6. Calendar year age model for the Lake Mapourika record based on ${ }^{14} \mathrm{C}$ dates from terrestrial leaf macrofossils isolated from hemipelagite. The chronological model was produced in OxCal 4.1 using the P_sequence algorithm and the SHCal 04 calibration curve (Bronk Ramsey, 2008; McCormac et al., 2004). The figure shows the calendar age likelihood (light grey) and posterior probability density functions (dark grey), as well as the age models at the 95\% level of confidence. Rapidly deposited layer (RDL) normalised core depth is the depth of the core with deposits such as, megaturbidites and hyperpycnal turbidites removed. 

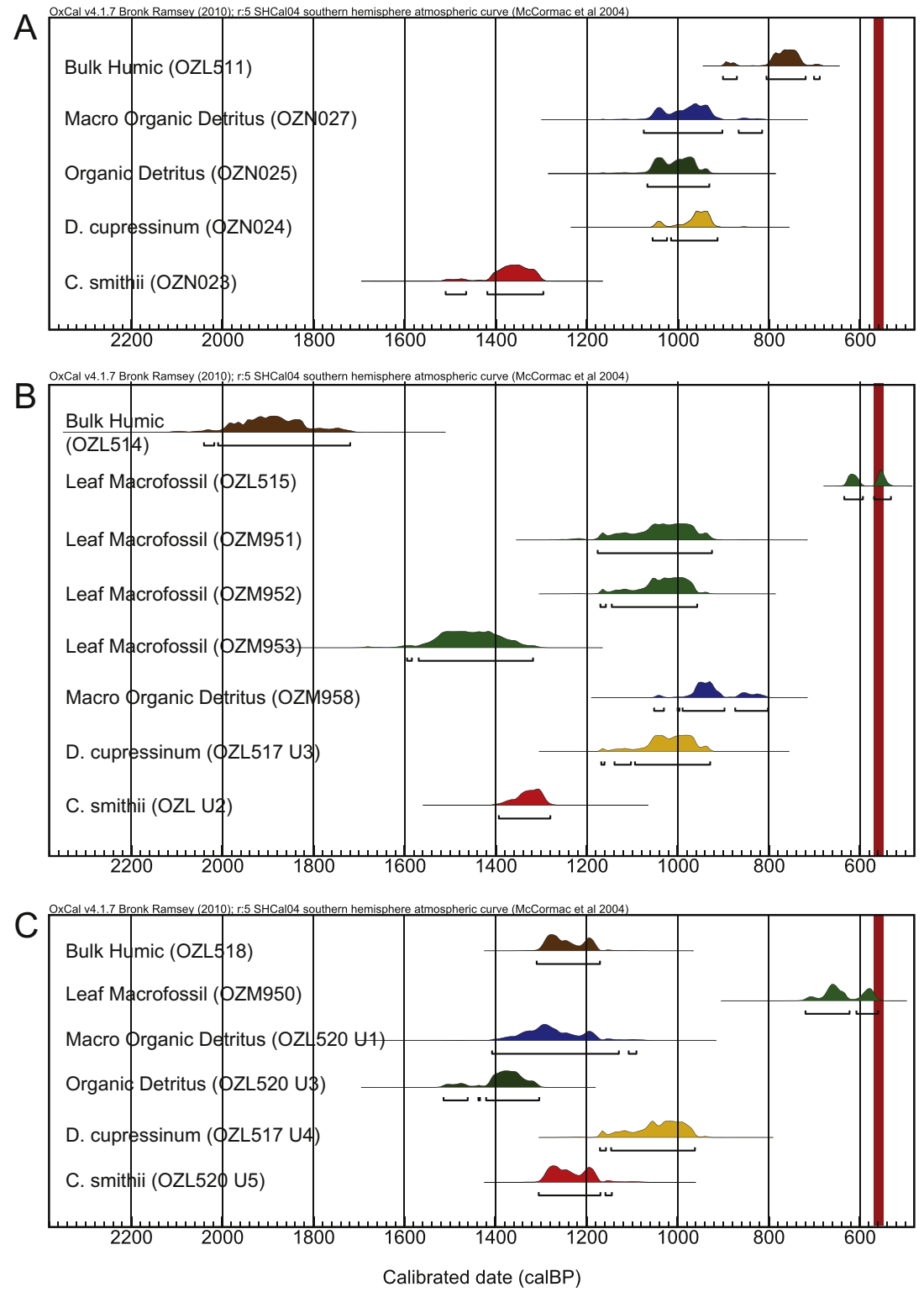

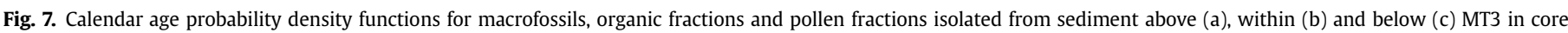

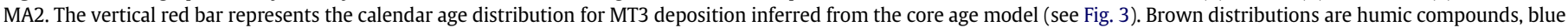

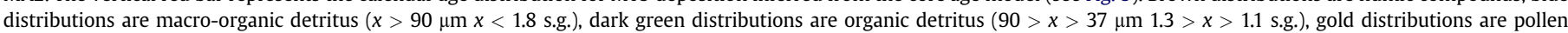

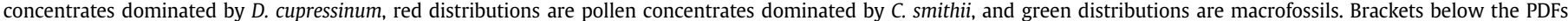
represent the 95\% HPDF ranges. (For interpretation of the references to colour in this figure legend, the reader is referred to the web version of this article.)

which again is an order of magnitude too old (Fig. 7C). All the other organic concentrates also provided ages older than the megaturbidite. The differences between the chronostratigraphic horizon age and the organic fractions ranged between 622 and 415 calendar years for the pollen concentrate predominantly composed of D. cupressinum, to between 969 and 757 calendar years for the organic detritus fraction. The pollen fraction dominated by C. smithii spores provided an age 315-45 calendar years older than the pollen concentrate composed of $D$. cupressinum pollen. Unlike the organic concentrates the terrestrial leaf macrofossil from below MT3 produced an age that was consistent with its position $5 \mathrm{~cm}$ below the chronostratigraphic horizon.

Pollen concentrates dominated by the podocarp $D$. cupressinum provided the most consistently young ages of the organic concentrates sampled from above, within and below MT3 from core MA2. The pollen concentrate enriched in $C$. smithii consistently provided one of the oldest ages. To verify this pattern pollen concentrates were also prepared from above and below MT3 in core MA1. The pollen concentrate dominated by $D$. cupressinum from below MT3 in this core provided the closest age to the chronostratigraphic horizon (Fig. 8; Table 4) but was between 736 and 522 calendar years too old, while the pollen concentrate enriched in $C$. smithii spores was between 1138 and 859 calendar years too old. The C. smithii-enriched pollen concentrate isolated from sediment above the megaturbidite provided a significantly younger age than its counterpart from sediment below the megaturbidite. Unfortunately, the graphitisation of the pollen concentrate enriched in D. cupressinum pollen was compromised and no age is available for this fraction, precluding a comparison of ages from above and below the megaturbidite. While the organic concentrates from core MA1 also produced anomalously old ages the terrestrial macrofossil extracted from directly below MT3 reproduced the age of the 
Table 4

${ }^{14} \mathrm{C}$ dates from above, within and below MT3 in cores MA1 and MA2.

\begin{tabular}{|c|c|c|c|c|c|c|}
\hline Sample & Fraction & Lab code & $\delta{ }^{13} \mathrm{C}(\%)$ & ${ }^{14} \mathrm{C}$ age (yr BP) & $\begin{array}{l}\text { 95\% HPDF calibrated } \\
\text { calendar age range (cal BP) }\end{array}$ & $\begin{array}{l}\text { Difference to MT3 } \\
\text { age (calendar yr) }\end{array}$ \\
\hline MA2MT3T & Bulk humin & OZL511 & $-24.0 \pm 0.1$ & $24,750 \pm 200$ & $24,371-25,175$ & $29,679-28,658$ \\
\hline MA2MT3T & Bulk humic & OZN026 & $-27.9 \pm 0.2$ & $905 \pm 30$ & $689-901$ & $358-144$ \\
\hline MA2MT3Т & Macro organic detritus $x>90 \mu \mathrm{m} x<1.8$ s.g. & OZN027 & $-27.7 \pm 0.1$ & $1115 \pm 50$ & $815-1135$ & $535-270$ \\
\hline MA2MT3T & Organic detritus $90>x>43 \mu \mathrm{m} 1.3>x>1.1$ s.g. & OZN025 & $-27.4 \pm 0.1$ & $1150 \pm 35$ & $931-1067$ & $525-385$ \\
\hline МА2МТ3Т & D. cupressinum pollen $43>x>25 \mu \mathrm{m} 1.3>x>1.1$ s.g. & OZN024 & $-28.0 \pm 0.1$ & $1100 \pm 35$ & $913-1056$ & $513-366$ \\
\hline MA2MT3T & C. smithii spores $25>x>10 \mu \mathrm{m} 1.3>x>1.1$ s.g. & OZN023 & $-28.4 \pm 0.1$ & $1530 \pm 40$ & $1296-1510$ & $961-748$ \\
\hline MA2MT3 & Bulk humin & OZL514 & $-23.8 \pm 0.2$ & $5115 \pm 40$ & $5746-5935$ & $5375-5185$ \\
\hline MA2MT3 & Bulk humic & OZL517U4 & $-28.5 \pm 0.4$ & $2000 \pm 60$ & $1720-2041$ & $1495-1177$ \\
\hline MA2MT3 & W. racemosa macrofossil & OZL515 & $-28.1 \pm 0.1$ & $620 \pm 25$ & $523-635$ & No difference \\
\hline MA2MT3 & W. racemosa macrofossil & OZM951 & $-26.5 \pm 0.2$ & $1170 \pm 60$ & $925-1176$ & $635-376$ \\
\hline MA2MT3 & W. racemosa macrofossil & OZM952 & $-25.6 \pm 0.1$ & $1180 \pm 40$ & $958-1170$ & $622-409$ \\
\hline MA2MT3 & Unknown leaf macrofossil & OZM953 & $-28.2 \pm 0.1$ & $1620 \pm 60$ & $1318-1595$ & $1047-775$ \\
\hline MA2MT3 & Macro organic detritus $x>90 \mu \mathrm{m} x<1.8$ s.g. & OZM958 & $-27.9 \pm 0.1$ & $1070 \pm 40$ & $1729-2054$ & $506-256$ \\
\hline MA2MT3 & D. cupressinum pollen $90>x>31 \mu \mathrm{m} 1.3>x>1.1$ s.g. & OZL517U3 & $-28.7 \pm 0.1$ & $1160 \pm 45$ & $929-1168$ & $593-382$ \\
\hline MA2MT3 & C. smithii spores $31>x>10 \mu \mathrm{m} 1.3>x>1.1$ s.g. & OZL517U2 & $-28.1 \pm 01$ & $1475 \pm 40$ & $1280-1393$ & $848-733$ \\
\hline МА2МТ3В & Bulk humin & OZL518 & $-21.9 \pm 0.1$ & $9510 \pm 60$ & $10,592-11,090$ & $10,532-10,034$ \\
\hline МА2МТ3В & Bulk humic & OZL520U6 & $-28.5 \pm 0.1$ & $1375 \pm 40$ & $1177-1300$ & $769-621$ \\
\hline МА2МТ3В & D. cupressinum macrofossil & OZM950 & $-28.2 \pm 0.1$ & $745 \pm 45$ & $609-724$ & $76-13$ \\
\hline МА2МТ3В & Macro organic detritus $x>90 x<1.8$ s.g. & OZL520U1 & $-29.1 \pm 0.2$ & $1420 \pm 70$ & $1091-1408$ & $862-547$ \\
\hline MA2MT3B & Organic detritus $90>x>37 \mu \mathrm{m} 1.3>x>1.1$ s.g. & OZL520U3 & $-28.8 \pm 0.2$ & $1550 \pm 35$ & $1304-1514$ & $969-757$ \\
\hline МА2МТ3В & D. cupressinum pollen $37>x>25 \mu \mathrm{m} 1.3>x>1.1$ s.g. & OZL520U4 & $-28.6 \pm 0.1$ & $1190 \pm 40$ & $962-1171$ & $622-415$ \\
\hline МА2МТ3В & C. smithii spores $25>x>10 \mu \mathrm{m} 1.3>x>1.1$ s.g. & OZL520U5 & $-27.8 \pm 0.1$ & $1365 \pm 40$ & $1145-1305$ & $764-599$ \\
\hline MA1MT3T & D. cupressinum pollen $43>x>25 \mu \mathrm{m} 1.3>x>1.1$ s.g. & OZN019 & $\mathrm{N} / \mathrm{A}$ & $\mathrm{N} / \mathrm{A}$ & $\mathrm{N} / \mathrm{A}$ & $\mathrm{N} / \mathrm{A}$ \\
\hline MA1MT3T & C. smithii spores $25>x>10 \mu \mathrm{m} 1.3>x>1.1 \mathrm{s.g}$. & OZN017 & $-28.6 \pm 0.1$ & $1330 \pm 30$ & $1093-1289$ & $747-550$ \\
\hline МА1MT3B & Twig macrofossil & OZM926 & $-24.8 \pm 0.1$ & $640 \pm 35$ & $540-651$ & No difference \\
\hline MA1MT3B & D. cupressinum pollen $37>\mathrm{x}>25 \mu \mathrm{m} 1.3>\mathrm{x}>1.1 \mathrm{s.g}$. & OZN018 & $-27.6 \pm 0.1$ & $1305 \pm 45$ & $1068-1279$ & $736-522$ \\
\hline MA1MT3B & C. smithii spores $25>x>10 \mu \mathrm{m} 1.3>x>1.1$ s.g. & OZN016 & $-27.0 \pm 0.4$ & $1685 \pm 40$ & $1409-1686$ & $1138-859$ \\
\hline
\end{tabular}

chronostratigraphic horizon. These results support the pattern of ages on pollen concentrates from core MA2.

\section{Discussion}

All the organic fractions dated provided calibrated calendar ages that were significantly older than the depositional age of MT3, which provides a chronostratigraphic horizon. The exceptions were terrestrial leaf macrofossils extracted from hempelagite deposits (Fig. 5). The data suggest that the dated organic concentrates contain carbon depleted in ${ }^{14} \mathrm{C}$ with respect to the atmosphere at the time of sediment deposition and consequently provide ages that are older than the timing of sediment deposition. These findings have important implications for: 1) understanding the sources of carbon in lake sediment; 2) conducting studies using pollen concentrates to date sediments in depositional environments where some material is sourced from the fluvial system; and 3) the importance of considering the depositional processes responsible for forming sedimentary deposits when selecting organic fractions that will produce reliable chronology in depositional settings dominated by fluvial inputs.

\subsection{Sources of carbon in lake sediments and implications for ${ }^{14} \mathrm{C}$ dating}

The ages and stable isotope composition of different organic fractions provides constraint on the sources of organic carbon from within the Lake Mapourika catchment (Table 4). For example, ${ }^{14} \mathrm{C}$ dating of bulk sediment humin resulted in ages that were consistently orders of magnitude too old, suggesting that a substantial proportion of the carbon was depleted in ${ }^{14} \mathrm{C}$ at the time of deposition. In addition, the bulk sediment humin fractions yielded $\delta{ }^{13} \mathrm{C}$ values that were two to six per mil higher than all the other organic fractions dated, suggesting that sediment humin is isotopically heavier than the other organic fractions. Recent analysis of the composition and sources of particulate organic carbon (POC)
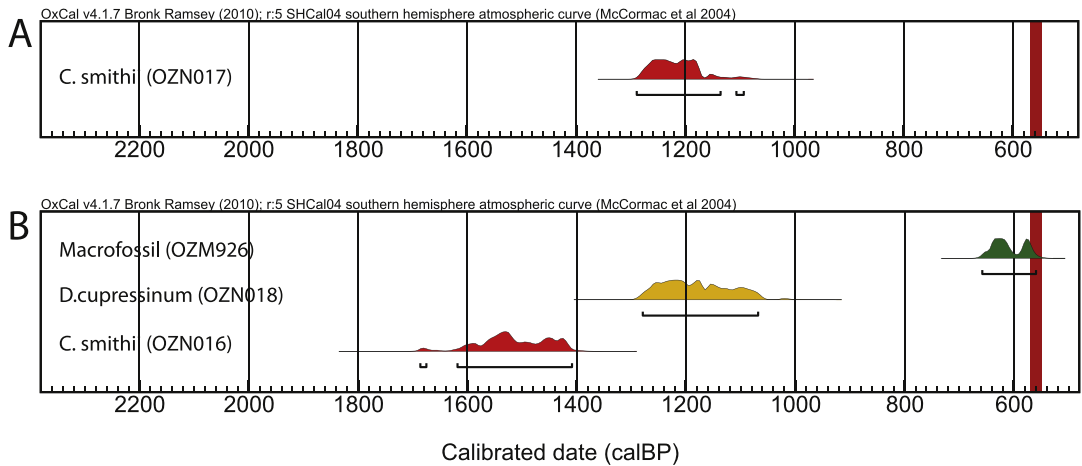

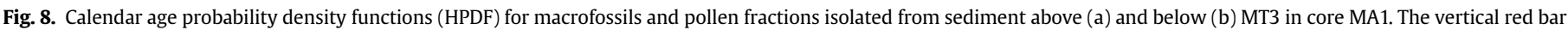

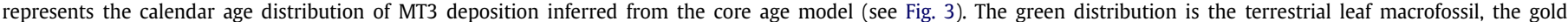

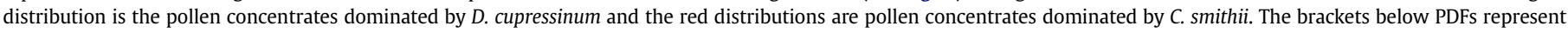
the 95\% HPDF ranges. (For interpretation of the references to colour in this figure legend, the reader is referred to the web version of this article.) 
derived from fluvial effluent in the Southern Alps has shown that an average $37 \%$ of POC discharged from mountain catchments in the Southern Alps is sourced from bedrock-derived fossil organic carbon (Hilton et al., 2008). The bedrock-derived fossil organic carbon is isotopically heavier than organic carbon derived from hillslope biomass (Hilton et al., 2008), and is depleted in ${ }^{14} \mathrm{C}$. Given the isotopically heavy nature of carbon in the bulk humin fraction and the relatively high abundance of fossil organic carbon in POC from fluvial effluent in the Southern Alps, it is likely that the ages provided by the bulk humin fraction are an order of magnitude older than the chronostratigraphic horizon due to inclusion of fossil organic carbon. By contrast, the $\delta{ }^{13} \mathrm{C}$ of all the other organic fractions were consistent with organic carbon sourced from hillslope biomass and therefore the erroneous ages produced by these fractions were probably due to the incorporation of "old" carbon from reworking of organic material in catchment soils or lake sediments.

The anomalous ages produced from pollen concentrates reinforce the interpretation that organic material is reworked from catchment soils. Soil palynology and dating show that $C$. smithii spores are preferentially preserved in catchment soils and that pollen concentrates dominated by these spores consistently provide ages up to 1138 calendar years older than the timing of sediment deposition. C. smithii-enriched pollen concentrates were also significantly older than pollen concentrates dominated by $D$. cupressinum. Older age determinations from $C$. smithii-enriched pollen concentrates are consistent with the interpretation that $C$. smithii spores are not only preferentially preserved in catchment soils but are also preferentially reworked from hillslopes to the lake basin through the fluvial system. The data show that it is possible to identify pollen types likely to be preferentially reworked from lake catchment soils and that removing these pollen types from pollen concentrates can increase the accuracy of ${ }^{14} \mathrm{C}$ dates. Such an approach has the potential to improve the accuracy of chronology in other depositional contexts where reworked pollen from catchment soils causes anomalies in ages derived from pollen concentrates (e.g. Kilian et al., 2002).

While removing $C$. smithii spores from pollen concentrates resulted in more accurate ages, these ages were still ca. 736-366 calendar years older than the timing of megaturbidite deposition. The slightly older ages suggest that either the small amount of nonpollen organic material in pollen concentrates biases the ${ }^{14} \mathrm{C}$ ages or that a proportion of all pollen types are sourced from catchment soils rather than solely from the atmospheric pollen rain. The latter explanation is considered more likely because the high purity of the pollen concentrates (Fig. 4), combined with the fact that pollen is more carbonaceous than other organic materials, make it unlikely that the small amount of organic detritus could deplete the sample ${ }^{14} \mathrm{C}$ concentration sufficiently to make the age appreciably older. Reworking of pollen through the fluvial system and into lake sediment violates the assumption that pollen is solely sourced from pollen rain from the atmosphere, and the corollary of this assumption, that the age of pollen is largely contemporaneous with sediment deposition. Consequently, it is important that studies reporting chronologies based on pollen concentrate dates provide some validation of the dating technique for their particular environmental setting. The results of this study suggest that such validation could be achieved by comparing ${ }^{14} \mathrm{C}$ dates on pollen concentrates with independent chronostratigraphic horizons where they are available.

\subsection{Towards a dating strategy for lakes with fluvial deposition regimes}

Ultimately, ${ }^{14} \mathrm{C}$ dating of the wide range of pollen and other organic concentrates evaluated in this study failed to provide accurate ages for the sediments of Lake Mapourika. The data show that macrofossils derived from terrestrial plants are the only source of organic material likely to yield accurate ${ }^{14} \mathrm{C}$ chronology from lake basins where a high proportion of sediment is derived from fluvial effluent. However, indiscriminate sampling of terrestrial macrofossils is also unlikely to produce reliable chronology. Wellpreserved terrestrial leaf macrofossils isolated from megaturbidite sediment provided a range of ages, which were up to 1047 calendar years older than the timing of sediment deposition. Such large discrepancies in age suggest that leaf material can be reworked by, and preserved during, the high-energy mass movement-evolved turbulent flows that result in megaturbidite deposition. On this basis macrofossils, or any other organic component, extracted from megaturbidites should not be selected as a target fraction for ${ }^{14} \mathrm{C}$ dating. Further, as macrofossils appear to be preserved during rapid depositional processes, such as turbulent flows, it is unlikely that terrestrial macrofossils will consistently produce accurate ages if they are isolated from any RDL produced from reworked material, whether they are mass flow, megaturbidite, or hyperpycnal turbidite deposits. This is particularly important because megaturbidites and hyperpycnal turbidites often contain abundant terrestrial macro-organic material that presents an attractive target for dating when organic material is scarce (e.g. Enters et al., 2006; Moy et al., 2011; Waldmann et al., 2011).

Our data suggest that terrestrial leaf material extracted from hemipelagite, which accumulates gradually, is the only organic material likely to provide accurate ${ }^{14} \mathrm{C}$ ages. Therefore, reliable chronology for the sedimentary records in lakes where fluvial effluent from catchments drives sedimentation can only be established by sampling terrestrial macrofossils from sediments that have not been reworked. This conclusion highlights the importance of combining rigorous physical sedimentology with any attempt to establish chronology using ${ }^{14} \mathrm{C}$ dating, because the depositional processes responsible for the formation of deposits provides important insight into the source of the carbon they contain.

While this study has focussed on an example where sedimentation from fluvial effluent from a steep catchment dominates deposition, the results are equally relevant for studies of lake sediments in lower energy environments. Most lakes, regardless of setting, are connected to the fluvial system and a component of sedimentation is sourced from inflow. Such fluvial inflow has the potential to transport pollen and organic material from catchment soils to lake basins, thereby complicating ${ }^{14} \mathrm{C}$ dating of organic material preserved in the sediment (e.g. Edwards and Whittington, 2001; Osleger et al., 2009). While the flux of reworked organic material may be lower in settings were fluvial sediment flux is more subdued, the longer residence times of soils within catchments means that reworked organic material has a greater potential to dilute the ${ }^{14} \mathrm{C}$ concentration of sediment. Furthermore, the frequency of RDL deposition may be reduced in lower energy depositional environments but these events still occur (e.g. Brown et al., 2000; Osleger et al., 2009), resulting in the potential for reworking of pollen and macrofossils from storage in the lake catchment or on subaqueous deltas and slopes. Consequently, the identification and removal of reworked pollen from pollen concentrates, together with the identification of RDL and avoidance of sampling from these deposits, has the potential to improve the accuracy of ${ }^{14} \mathrm{C}$ dates in most lake settings.

\section{Conclusion}

The results of the study demonstrate that the accuracy of ${ }^{14} \mathrm{C}$ chronologies relies on selection of appropriate targets for ${ }^{14} \mathrm{C}$ dating. In lakes where fluvial sedimentation is a prominent depositional process, extreme caution must be used when selecting samples for ${ }^{14} \mathrm{C}$ dating. Soil palynology and dating have 
demonstrated that pollen is preserved in catchment soils and reworked into lake sediments. The incorporation of reworked pollen into lake sediments dilutes the ${ }^{14} \mathrm{C}$ content of pollen concentrates with respect to the atmosphere at the time of deposition, producing ages that are too old. Removing pollen types that are preferentially preserved in soils improves the accuracy of ages but not sufficiently to make them reliable. This conclusion is true for all organic fractions extracted from sediment with the exception of terrestrial leaf marcofossils. Caution must still be exercised when targeting terrestrial leaf macrofossils for dating because even these delicate targets are reworked and preserved during rapid depositional processes such as turbulent flows.

We conclude that thorough physical sedimentological investigations should always precede the selection of samples for ${ }^{14} \mathrm{C}$ dating and where possible only terrestrial leaf material extracted from sediment that has accumulated gradually should be selected. If terrestrial leaf macrofossils are not available then other organic fractions, such as pollen concentrates with reworked pollen grains removed, should be given preference, while at the same time acknowledging that ages based on such pollen concentrates may still be inaccurate. This is particularly relevant to situations where modelling of ${ }^{14} \mathrm{C}$ datasets is used to produce high precision chronologies. If reworked organic material is not identified and accounted for, then the chronologies may have systematic inaccuracies far greater than the reported precision.

\section{Acknowledgements}

We would like to thank $\operatorname{Dr}$ C. Prior and F. Bertuch for training and assistance with sample pretreatment. Dr Paul Augustinus provided the sediment from Pukaki Maar used as a blank in the preparation of pollen concentrates. The research was funded by a Tertiary Education Commission Bright Futures TADS contract UOOX0815, Australian Institute of Nuclear Science and Engineering PGRA (Postgraduate Research Award) contract AINSTU0808, GNS Science Public Good Science Fund Subcontract C05X0907, and the University of Otago. The manuscript benefited from constructive reviews by Jesper Olsen, Fadil Inceoglu and an anonymous reviewer.

Editorial handling by: T. Higham

\section{References}

Beck, C., 2009. Late quaternary lacustrine paleo-seismic archives in north-western Alps: examples of earthquake-origin assessment of sedimentary disturbances. Earth Science Reviews 96, 327-344.

Bertrand, S., Araneda, A., Vargas, P., Jana, P., Fagel, N., Urrutia, R., 2012. Using the N/C ratio to correct bulk radiocarbon ages from lake sediments: insights from Chilean Patagonia. Quaternary Geochronology 12, 23-29.

Blockley, S.P.E., Blaauw, M., Bronk Ramsey, C., Van Der Plicht, J., 2007. Building and testing age models for ${ }^{14} \mathrm{C}$ dates in Lateglacial and Early Holocene sediments. Quaternary Science Reviews 26, 1915-1926.

Bronk Ramsey, C.B., 2008. Deposition models for chronological records. Quaternary Science Reviews 27, 42-60.

Bronk Ramsey, C., 2010. OxCal Program, V. 4.1. Radiocarbon Accelerator Unit, University of Oxford, UK. https://c14.arch.ox.ac.uk/oxcal.html.

Brown, T.A., Nelson, D.E., Mathewes, R.W., Vogel, J.S., Southon, J.R., 1989. Radiocarbon dating of pollen by accelerator mass spectrometry. Quaternary Research 32, 205-212.

Brown, S.L., Bierman, P.R., Lini, A., Southon, J., 2000. 10000 yr record of extreme hydrologic events. Geology 28, 335-338.

Chester, P.I., Prior, C.A., 2004. An AMS 14C pollen-dated sediment and pollen sequence from the later Holocene, southern coastal Hawke's Bay, New Zealand. Radiocarbon 46, 721-731.

Colman, S.M., Bradbury, J.P., McGeehin, J.P., Holmes, C.W., Edginton, D., SarnaWojcicki, A.M. 2004. Chronology of sediment deposition in Upper Klamath Lake, Oregon. Journal of Paleolimnology 31, 139-149.

Edwards, K.J., Whittington, G., 2001. Lake sediments. Erosion and landscape change during the Holocene in Britain and Ireland. Catena 42, 143-173.

Enters, D., Kirchner, G., Zolitschka, B., 2006. Establishing a chronology for lacustrine sediments using a multiple dating approach - a case study from the Frickenhauser See, central Germany. Quaternary Geochronology 1, 249-260.
Faegri, K., Iversen, J., 1989. Textbook of Pollen Analysis, fourth ed. John Wiley and Sons, London.

Fink, D., Hotchkis, M., Hua, Q., Jacobsen, G., Smith, A., Zoppi, U., Child, D., Mifsud, C., van der Gaast, H., Williams, A., 2004. The ANTARES AMS facility at ANSTO. Nuclear Instruments and Methods in Physics Research Section B: Beam Interactions with Materials and Atoms 223, 109-115.

Grimms, G.A., 1991. Tilia Version 1.10. Illinios State Museum, Reserve Collection Centre, Illinois.

Grimms, G.A., 1995. TGView Version 2.0.2. Illinios State Museum, Reserve Collection Centre, Illinois.

Hilton, R.G., Galy, A., Hovius, N., 2008. Riverine particulate organic carbon from an active mountain belt, importance of landslides. Global Biogeochemical Cycles 22, GB1017, http://dx.doi.org/10.1029/2006GB002905.

Howarth, J.D., Fitzsimons, S.J., Norris, R., Jacobsen, G.E., 2012. Lake sediments record cycles of sediment flux driven by large earthquakes on the Alpine Fault, New Zealand. Geology 40, 1091-1094.

Howarth, J. D. 2012. Reconstructing the landscape response to earthquakes on the Alpine Fault, New Zealand. Unpublished PhD thesis. University of Otago, New Zealand.

Hua, Q., Jacobsen, G.E., Zoppi, U., Lawson, E.M., Williams, A.A., McGann, M.J., 2001. Progress in radiocarbon target preparation at the ANTARES AMS Centre. Radiocarbon 432, 275-282.

Irwin, J., 1979. Lake Mapourika: 1:10,000 Bathymetry. In: N. Oceanogr. Inst. Chart, Lake Series.

Kilian, M.R., Van Der Plicht, J., Van Geel, B., Goslar, T., 2002. Problematic C-14-AMS dates of pollen concentrates from Lake Gosciaz (Poland). Quaternary International 88, 21-26.

Large, M.F., Braggins, C.J., 1991. Spore Atlas of New Zealand Ferns and Fern Allies. DSIR Publishing, Wellington.

Last, W.M., Smol, J.P., 2001. Physical and geochemical methods. In: Last, W.M. (Ed.) Tracking Environmental Change Using Lake Sediments. In: Smol, J.P. (Ed.), Physical and Geochemical Methods, vol 2. Kluwer Academic Publishers, Dortrecht, p. 504.

Long A., Davis, O.K., De Lanois, J., 1992. Separation and ${ }^{14} \mathrm{C}$ dating of pure pollen from lake sediments, nanofossil AMS dating. Radiocarbon 34, 557-560.

McGlone, M.S., Wilmshurst, J.M., 1999. Dating initial Maori environmental impact in New Zealand. Quaternary International 59, 5-16.

McCormac, F.G., Hogg, A.G., Blackwell, P.G., Buck, C.E., Higham, T.F.G., Reimer, P.J., 2004. SHCal04 Southern Hemisphere calibration, 0-11.0 cal kyr BP. Radiocarbon 46, 1087-1092.

Mensing, S.A., Southon, J.R., 1999. A simple method to separate pollen for AMS ${ }^{14} \mathrm{C}$ dating and its application to lacustrine and marine sediments. Radiocarbon 41, $1-8$

Moar, N.T., 1993. Pollen Grains of New Zealand Dicotyledonous Plants. Maanaki Whenua Press, Lincoln, New Zealand. 200pp.

Moar, N.T., Wilmshurst, J.M., McGlone, M.S., 2011. Standardizing names applied to pollen and spores in New Zealand Quaternary palynology. New Zealand Journal of Botany 49, 201-229.

Moy, C.M., Dunbar, R.B., Moreno, P.I., Francois, J.-P., Villa-Martnez, R., Mucciarone, D.M., Guilderson, T.P., Garreaud, R.D., 2008. Isotopic evidence for hydrologic change related to the westerlies in SW Patagonia, Chile, during the last millennium. Quaternary Science Reviews 27, 1335-1349.

Moy, C.M., Dunbar, R.B., Guilderson, T.P., Waldmann, N., Mucciarone, D.A., Recasens, C., Ariztegui, D., Austin, J.A., Anselmetti, F.S., 2011. A geochemical and sedimentary record of high southern latitude Holocene climate evolution from Lago Fagnano, Tierra del Fuego. Earth and Planetary Science Letters 302, 1-13.

Newnham, R.M., Vandergoes, M.J., Garnett, M.H., Lowe, D.J., Prior, C., Almond, P.C., 2007. Test of AMS ${ }^{14} \mathrm{C}$ dating of pollen concentrates using tephrochronology. Journal of Quaternary Science 22, 37-51.

Oldfield, F., Crooks, P.R.J., Harkness, D.D., Pettersen, G., 1997. AMS radiocarbon dating of organic fractions from varved lake sediments, an empirical test of reliability. Journal of Paleolimnology 18, 87-91.

Osleger, D.A., Heyvaert, A.C., Stoner, J.S., Verosub, K.L., 2009. Lacustrine turbidites as indicators of Holocene storminess and climate: lake Tahoe, California and Nevada. Journal of Paleolimnology 42, 103-122.

Pocknall, D.T., 1981a. Pollen morphology of the New Zealand species of Dacrydium Solander, Podocarpus L'Heritier and Dacrycarpus Endlicher (Podocapaceae). New Zealand Journal of Botany 19, 67-95.

Pocknall, D.T., 1981b. Pollen morphology of Phyllocladus L. C. et Rich. New Zealand Journal of Botany 19, 259-266.

Reimer, P.J., Baillie, M.G.L., Bard, E., Bayliss, A., Beck, J.W., Blackwell, P.G., Bronk Ramsey, C., Buck, C.E., Burr, G.S., Edwards, R.L., Friedrich, M., Grootes, P.M., Guilderson, T.P., Hajdas, I., Heaton, T.J., Hogg, A.G., Hughen, K.A., Kaiser, K.F. Kromer, B., McCormac, F.G., Manning, S.W., Reimer, R.W., Richards, D.A., Southon, J.R., Talamo, S., Turney, C.S.M., van der Plicht, J., Weyhenmeyer, C.E., 2009. IntCal09 and Marine09 radiocarbon age calibration curves, 0-50,000 years cal BP. Radiocarbon 51, 1111-1150.

Rijkse, W.C., Hewitt, A.E., 1995. Soil Map of the South Island, New Zealand Soil Classification 1:1000000 Scale. Manaaki Whenua-Landcare Research, Lincoln, New Zealand.

Schnellmann, M., Anselmetti, F.S., Giardini, D., Mckenzie, J.A., Ward, S.N., 2002. Prehistoric earthquake history revealed by lacustrine slump deposits. Geology 30, 1131-1134.

Stuiver, M., Polach, H.A., 1977. Discussion: reporting of ${ }^{14} \mathrm{C}$ data. Radiocarbon 19 , $355-363$ 
Sutherland, R., Eberhart-Phillips, D., Harris, R.A., Stern, T., Beavan, J., Ellis, S., Henrys, S., Cox, S., Norris, R.J., Berryman, K.R., Townend, J., Bannister, S. Pettinga, J., Leitner, B., Wallace, L., Little, T.A., Cooper, A.F., Yetton, M., Stirling, M., 2007. Do great earthquakes occur on the Alpine Fault in central South Island, New Zealand? In: Okaya, D., Stern, T., Davey, F. (Eds.), A Continental Plate Boundary: Tectonics at South Island, New Zealand Geophysical Monograph Series, vol. 175, pp. 235-251.

Turney, C.S.M., Coope, G.R., Harkness, D.D., Lowe, J.J., Walker, M.J.C., 2000. Implications for the dating of Wisconsinan Weichselian. Late-glacial events of systematic radiocarbon age differences between terrestrial plant macrofossils from a site in SW Ireland. Quaternary Research 53, 114-121.

Vandergoes, M.J., Fitzsimons, S.J., 2003. The last glacial-interglacial transition (LGIT) in south Westland, New Zealand: paleocological insight into mid-latitude southern Hemisphere climate change. Quaternary Science Reviews 22, 1461-1476.

Vandergoes, M.J., Prior, C.A., 2003. AMS dating of pollen concentrates-a methodological study of late Quaternary sediments form South Westland, New Zealand. Radiocarbon 45, 479-491.
Waldmann, N., Anselmetti, F.S., Ariztegui, D., Austin, J.J.A., Pirouz, M., Moy, C.M. Dunbar, R., 2011. Holocene mass-wasting events in Lago Fagnano, Tierra del Fuego $54^{\circ} \mathrm{S}$, implications for paleoseismicity of the Magallanes-Fagnano transform fault. Basin Research 23, 171-190.

Wardle, P., 1980. Primary succession in Westland National Park and its vicinity, new Zealand. New Zealand Journal of Botany 18, 221-232.

Wardle, P., 1991. Vegetation of New Zealand. Cambridge University Press, England, $672 \mathrm{pp}$.

Wells, A., Yetton, M.D., Duncan, R.P., Stewart, G.H., 1999. Prehistoric dates of the most recent Alpine Fault earthquakes, New Zealand. Geology 27, 995-998.

Wilmshurst, J.M., Eden, D., Froggatt, P.C., 1999. Late Holocene forest disturbance in Gisborne, New Zealand: a comparison of terrestrial and marine pollen records. New Zealand Journal of Botany 37, 523-540.

Wilmshurst, J.M., McGlone, M., 2005. Origin of pollen and spores in surface lake sediments, comparison of modern palynomorph assemblages in moss cushions, surface soils and surface lake sediments. Review of Palaeobotany and Palynology $136,1-15$. 